\title{
The Construction of Chinese Indonesians in Ngenest Film
}

\section{Yoel Christian}

English Department, Faculty of Languages and Literature, Petra Christian University, Siwalankerto 121131, Surabaya 60236, INDONESIA

E-mail:m11415043@john.petra.ac.id

\begin{abstract}
The thesis focuses on how Chinese Indonesians are constructed in Ngenest and why they are constructed that way. Chinese Indonesians become a scapegoat and considered bad ethnic group since they are the minority. By using the Ethnic Construction and Stereotype theory it helps me to reveal the constructions of Chinese Indonesians in Ngenest, and also why they are constructed that way. I would analyze the Chinese Indonesian major and minor characters in Ngenest. This can be revealed from the way they interact with the society in Ngenest. In conclusion, Chinese Indonesians are not accepted as one's own in their land because of their construction as perpetual foreigners, being loyal to Chinese traditions which makes them different from the rest of the Indonesian society, and being rich by exploiting non-Chinese Indonesians. Since the Chinese Indonesians are the minority, they become a scapegoat and target of nonChinese Indonesians in the society.
\end{abstract}

Keywords: racism, ethnic construction, stereotyping, representation, Chinese Indonesians

\section{INTRODUCTION}

Comedy film, by Oxford Dictionary's definition, is a film that is intended to be funny, usually with a happy ending (Oxford Learner's Dictionaries online). It is an entertainment that people always seek to relieve their stress and to find an escape because of the laughter and joy that the film can deliver. Comedy film reaches its popularity in Indonesia in the 1980s, when the Warkop DKI series, starred by Dono, Kasino, and Indro as the main characters, were popular. Makbul Murbarak, a critic and film-maker of Indonesia, believed that this series gained around 40 million viewers in that era (Theresia, 2018). Based on the Central Bureau of Statistics, Comedy film has ranked 5th of the most played genre in theatres in 2014 (Katadata, 2016). The popularity of comedy films is also supported by Pramantie (2017) who writes that four of the ten most-watched films in Indonesia are comedy films. Even, old comedy film remakes are also very popular nowadays as in the case of the most-watched comedy film, Warkop DKI Reborn: Jangkrik Boss Part 1, that is watched by 6.85 million (Pramantie, 2017).

Ernest Prakasa one of the famous film directors in Indonesia has successfully made three of his comedy films watched by more than 5.3 million viewers, and won five recognizable appreciations in Indonesia. He has won a prestigious Citra trophy as the best scriptwriter in 2017 (Afrisia, 2017) and two Maya trophies as a scriptwriter in 2016 and 2017 (Perdana, 2016); (Hawari, 2017). His first film is Ngenest that has 785 thousand of viewers, his second film is Cek Toko Sebelah that has 2.5 million of viewers, and his third film is Susah Sinyal that has 2.17 million of viewers (Diananto, 2017) (Diananto, 2018). An interesting fact about Ernest Prakasa is that he uses Chinese Indonesian as the main characters in his first two films, Ngenest, and Cek Toko Sebelah. Using Chinese Indonesians as the main characters in a film is very interesting because Chinese Indonesians rarely get the role of the main character in a film here in Indonesia. Usually, non-Chinese Indonesians dominate the main characters of most films. From the top ten list of best-selling films in 2018, only A Man Called Ahok that has a Chinese Indonesian as the main character (Wahyudi, 2018). Because Chinese Indonesian is not 
frequently preferred in most films in Indonesia, making Chinese Indonesian as the main character in a successful film is a very interesting topic to discuss. Moreover, the new phenomenon of using Chinese Indonesian as the main character in a film is also very interesting because their ethnicity has made them "invisible" in the eyes of Indonesian citizens (Williams, 1989 pp. 420). In other words, because they are often considered ethnically foreign, they are seen as "the other", which means that they are not part of "the self" which renders Chinese ethnicity invisible.

Ngenest attracts my attention because the film reveals mostly the life of Chinese Indonesian here in Indonesia because the film is based on the real story of the director, Ernest Prakasa. The film has been watched by 785 thousand of viewers and ranked in the list of Box Office at that time (Djaya, 2016). Interestingly, making Chinese Indonesian as the focus of the film has successfully brought lots of audiences at that time, even though Chinese Indonesian people are the minority in Indonesia.

Moreover, in Ngenest, a comedy film that is produced based on the life of Ernest Prakasa, is a film that explores the life of a Chinese Indonesian. Ernest uses his real-life experience as the foundation of the plot of the story. He believes that to make a successful film is to be sensitive to the surroundings and to focus on every little thing that happens in life (Viva, 2018). Ngenest explores the story of Chinese Indonesian struggles that is why it attracts my attention as a Chinese Indonesian. The main character, Ernest, faces many problems that make me aware of his problems as a Chinese Indonesian. The story of the film shows that Chinese Indonesian has two problems. They are considered as foreigners because of their ethnicity even though they have their Indonesian citizenship, and the non-Chinese Indonesians extort them because they are believed to be rich.

Ethnic construction and stereotype theory are the theories that I will use in this analysis. Ethnicity is socially constructed. In other words, ethnicity is a product of the society. Language, religion, culture, appearance, ancestry, and regionality are the elements that construct ethnicity (Nagel, 1994). Ethnicity helps people to define a group of people, not only by their physical traits but also by differences in language, religion, region, or culture. It is a broader concept of race (Nagel, 2000). Race is a concept that only focuses on facial or physical traits, but ethnicity focuses on the wider concept (Diffen, n.d.). Throughout the years, ethnicity changes over time, it does not have a fixed categorization. Since language, religion, region, and culture keep changing, ethnicity will also change its boundaries. It is like a fluid that adapts to the elements that construct it (Nagel, 1994). In other words, the fluidity in ethnic construction makes it a never ending-process, dependent upon the dynamics in the society. The theory of Ethnic Construction helps me in analyzing how Chinese Indonesians are constructed in Ngenest. It helps me to see the construction of Chinese Indonesian ethnicity in this film based on the society's construction in Ngenest film.

Stereotyping is making each person look the same to one another. Lippman said that people do not first see and then they define, but people define first and then see the reality (Lippman, 1927). It means that people directly take what the Culture has defined, and apply it into their belief. In other words, Stereotype makes society neglect the differences in every individual, and believe in what the culture has defined for them. Which is later used as labels to define certain groups of people. In other words, Stereotype simplifies the complexity of the society. Lippman believes that each person lives in a very small part or a very small circle of this world. Since the world is very big and it is very hard to process and to understand this very world, stereotype takes place as a solution to see the whole world in a simplified way (Lippman, 1927). The simplified meaning become something that is not based on facts that become the foundation to label or to define each group of people. The role of stereotype is to define each ethnic group, which makes people overgeneralize a group of people without facts as their foundation because 
stereotype is maintained only by the medium of communication. I will use stereotype theory to analyze the reason why Chinese Indonesians are constructed as such by the society.

\section{THE CONSTRUCTION OF CHINESE INDONESIANS IN NGENEST FILM}

Ethnicity construction is not a form that lasts forever. It is a construction that differs from time to time because of the society that keeps changing. According to Nagel, ethnicity is elastic because of its dynamics that will continue to change (1994, p. 152-153). Since its construction is the product of society, ethnicity is fluid and keeps adapting to the dynamics in the society. The ethnic boundary helps to define and differ groups of people from the line that separates each ethnic group. Moreover, the ethnic construction that is made by the society will help people to see and categorize their social world. According to Lippman, in seeing and categorizing their social world, people tend to make stereotypical images of their social world (Lippman, 1922, p.31). The process of stereotyping results in labelling. Labelling usually takes place when ethnic construction is revealed (Nagel, 1994, p.152). The ethnic construction that involves stereotypes shows that society often labels other people. The process of labelling produces a simplification of their understanding of others. This can be seen in Ngenest. In Ngenest, Chinese Indonesians are stereotypically portrayed since they are constructed as "the other". In this analysis, I will explain the way Chinese Indonesians are constructed using ethnicity construction and I will also explain why they are constructed that way using stereotype as the working theory.

\subsection{The Ways Chinese Indonesians Are Constructed}

In Ngenest film, there are lots of Chinese Indonesian characters that appear in this film because the main focus of the film is on the story of Ernest Prakasa. There are minor and also major Chinese Indonesian characters. The major characters that will be used in this analysis are Ernest, Patrick, and Ernest's Parents. Ernest first appears at the beginning of the film as a baby along with his parents. The film follows him until the day Ernest's first child is born. Patrick first appears as a child in elementary school and he accompanies Ernest until the end of the film. The minor characters are the characters that are shown only to support the plot of the story. For example, the Chinese Indonesian kid that is being bullied at the beginning of the film or the Chinese Indonesian student who beats up the bullies. Several pieces of evidence show the way Chinese Indonesians are constructed in Ngenest, that is, they are constructed as perpetual foreigners and being rich.

\subsubsection{Perpetual Foreigners}

In Ngenest, Chinese Indonesians are being constructed as perpetual foreigners. It means that the minority ethnic group will always be viewed as the "other" in the majority ethnic group (Huynh, Devos, Smalaraz, 2011). In other words, it is an act that denies the existence of the minority ethnic group which makes them not accepted as one's own. Moreover, the Chinese Indonesians have been recognized in the political records as the citizens of Indonesia, but all of the Chinese Indonesian characters in Ngenest are pictured as foreigners. Since the beginning of the story, Chinese Indonesians have been seen as the "other". There is always a gap between Chinese Indonesian and non-Chinese Indonesian. With this idea in the head of the majority group, the non-Chinese Indonesians will keep separating themselves from the Chinese Indonesians by drawing an ethnic boundary line. However, some people accept non-Chinese Indonesians as one's own. 


\subsubsection{Phenotypical Image}

Non-Chinese Indonesians see Chinese Indonesian as the "other" by first categorizing them from their physical looks. There has to be a classification that separates between non-Chinese Indonesian and Chinese Indonesian. In the first scene of Ngenest, Chinese Indonesian is directly seen as a group of foreigners. Ernest first states his idea of being born into a family in the voice over. His idea is that no one can choose where they want to be born. The voice-over ends with highlighting the statement of his story of being born into a Chinese family. The moment he finishes his statement, the bullying by the two non-Chinese Indonesian kids starts. In this scene, the two non-Chinese Indonesian kids are very excited judging by the wide smile of the first nonChinese Indonesian kids when they look at a Chinese Indonesian kid walking by himself. The first non-Chinese Indonesian kid that appears first in this scene directly persuades the other nonChinese Indonesian kid to bully the Chinese Indonesian kid. It is seen from the way the kid engages by looking at the other kid excitingly and throwing one of his hand up. The moment that these Non-Chinese Indonesians say, "Chinese!" is the moment that the Chinese Indonesian kid feels separated from these non-Chinese Indonesian kids. Judging by his look, this kid directly feels a lack of confidence with his identity. It is shown when he looks down after he is judged for being a "Chinese" by the non-Chinese Indonesian kids. However, before they arrive to the idea of categorizing who is a Chinese Indonesian, there is the idea behind that to identify and differentiate each ethnic in the Indonesian people's mind. One of which is through the physical appearance or the phenotypical image. Phenotype has a role in categorizing people into some ethnic groups (Feliciano, 2016). Through the phenotypical image, people are able to judge who is a Chinese Indonesian and who is a non-Chinese Indonesian. The two non-Chinese Indonesian kids differentiate the Chinese Indonesian kid's ethnicity by directly looking at the physical appearance. As seen in picture 1, the kid is being judged as Chinese because of the look that he has.

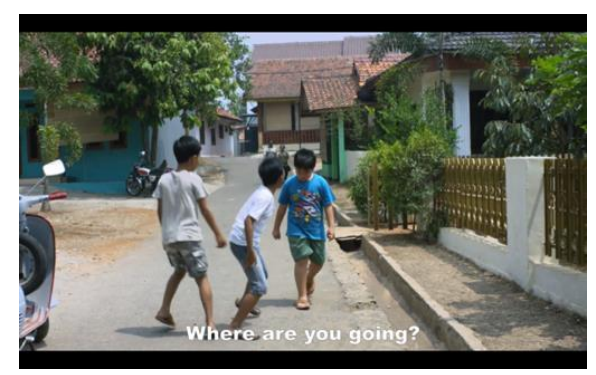

Picture 1: A Chinese kid is being bullied by the other non-Chinese Kids (Ngenest; 2015, 00:00:05 )

Compared to the other two non-Chinese Indonesian kids, he has lighter skin and also smaller eyes. This shows that ethnically he is different from the non-Chinese Indonesian. With these two simple phenotype identifications, the non-Chinese Indonesian kids can identify his Ethnicity which results in calling the kid a Chinese. This identification shows an ethnic boundary between Chinese Indonesians and non-Chinese Indonesians according to Nagel (1994). The phenotypical features that are different compared to the non-Chinese Indonesians become the standard to differ the non-Chinese Indonesian ethnicity.

\subsubsection{Outsiders}

Chinese Indonesians are depicted as a perpetual foreigner because they are also seen as outsiders. There is an invisible wall that separates between the Chinese Indonesians and the non-Chinese Indonesians in Ngenest. In the next discussion, Ernest can be seen directly that he is not accepted in his school as one of them in his first day of school just because of having a Chinese Indonesian ethnicity. Ernest is calmly walking alone to his class, and suddenly he 
meets a group of non-Chinese Indonesian kids standing in front of the class entrance. From afar, Bowo who is a non-Chinese Indonesian kid sees Ernest and tells his friends that there is a Chinese Indonesian. Then, Bakri and Bowo laugh together when they see Ernest. The moment Ernest arrives in front of the non-Chinese group, Faris introduces him to the members of the group. However, when Ernest introduces himself that he is Ernest and he is from the 1B class, he is rejected by the mockery that the group of kids makes. Interestingly, Acong is used to call Ernest, although Ernest has introduced himself to them. Acong refers to a name calling for Chinese Indonesian group of people. They also make a joke that he is supposed to be in the 1C class because he is Chinese. They believe that C stands for "Cina" and "Cipit", in other words, Chinese and Slanted. The repetition of calling Chinese Indonesian using derogatory labels such as Acong and Cipit (Slanted) shows that the non-Chinese consider themselves as "the self" while the Chinese as "the other" (Hall, 1991).

From the analysis of this scene, even though Ernest is born in Jakarta, has Indonesian parents and speaks fluent Indonesian language, his friends see him as a perpetual foreigner instead of an Indonesian because Ernest is a Chinese Indonesian. They do not accept him as one's own in the same class. If it's just a joke, Ernest will also laugh. However, from the expression that is shown in picture 6, Ernest does not feel happy with the statements that the kids say. He feels that his identity is being rejected and he is marginalized by the majority ethnic group. The younger generation society in Ngenest shows that there is a huge gap between Chinese Indonesian and non-Chinese Indonesian. This shows that Chinese Indonesians are seen as "the other" in the younger generation society. Chinese Indonesian is marginalized because of their ethnicity. They are rejected by the non-Chinese Indonesian only because they are Chinese Indonesian.

\subsubsection{Loyal to Chinese Traditions}

The perception that Chinese Indonesians are Perpetual foreigners are supported by their adherence to a "different" culture. Chinese Indonesians follow the culture that is passed down by their ancestors from China, which is why their culture is similar to the culture that is celebrated in China. This strengthens the non-Chinese Indonesians' view of a Chinese Indonesian as a perpetual foreigner because of their adherence to Chinese Culture. Chinese Indonesians' adherence to Chinese culture is seen through the depiction of Chinese traditions, such as a wedding ceremony and a Chinese New Year event in Ngenest.

Wedding ceremony often becomes an avenue for celebrating traditional and cultural rituals. Because of this reason, Chinese Indonesians often conduct their wedding ceremony according to the Chinese culture. According to Kuntjara, Suprajitno, and Mochtar, the Chinese Indonesian wedding ceremony is an event that shows how Chinese Indonesians survive their Chineseness (2018, p. 4).

The wedding ceremony of Ernest and Meira as depicted in Ngenest shows that although Meira is a Sundanese, the ceremony of her wedding follows Ernest's family tradition, that is, following Chinese tradition. As seen in picture 2, Ernest is taking a picture with Meira and their family in this scene on the stage. 


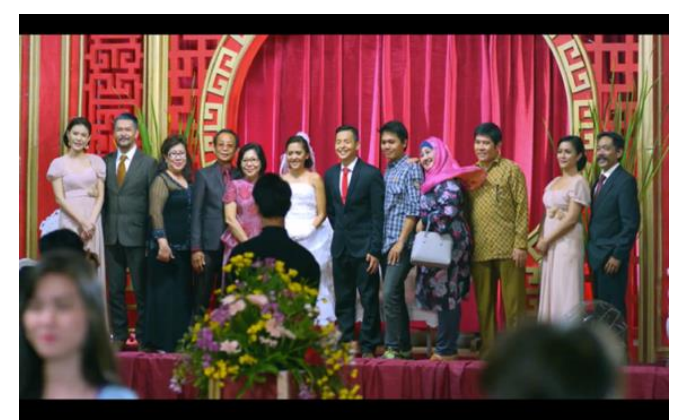

Picture 2: Ernest and Meira's wedding day (Ngenest; 2015, 00:50:05 )

As seen in picture 8, the backdrop is filled with Chinese ornaments, such as red as the main color of the theme, Chinese lanterns in the ceiling, and the ornaments or symbols of the background of the stage. These elements that decorate the theme of the wedding represents a Chinese wedding ceremony. The use of Chinese-inspired ornaments and decorations shows that the bride and the groom are Chinese. Although Ernest is an Indonesian citizen, his wedding ceremony is full of Chinese cultural elements and tradition. This reflects that his family follows their ancestor's traditions. The fact that Ernest and his family members do not speak Chinese and they do not know much about their Chinese heritage shows that in an important event, like a wedding, they still follow Chinese traditions. This means that they are loyal to Chinese traditions. Even the entertainment at the wedding ceremony is very Chinese. Picture 9 shows that the song that the singer sings is a Chinese song in Ernest and Meira's wedding. This kind of entertainment, that is, singing Chinese songs is always found in Chinese weddings in Indonesia. Even the entertainment at the wedding ceremony shows its Chinese characteristics, which is different from the wedding ceremony of non-Chinese Indonesians.

The analysis in this part shows that although Chinese Indonesians are the citizens of Indonesia, they are seen as "different" due to their phenotypical features. This results in their being labelled as outsiders. Their label as perpetual foreigners is also reinforced by the perception that they are culturally different from the rest of the society. How they adhere to Chinese tradition makes the rest of the society see them as also a perpetual foreigner. Moreover, they are seen as "kaum keturunan", which implies that Chinese Indonesians are not an original part of the Indonesian nation. Although they are Indonesian citizens, according to Thung, Indonesian society classifies both Chinese who are Indonesian citizens and Chinese who are foreigners into one group (2012, p. 374). Their physical difference as well as the label as the outsiders make them perpetual foreigners even though they have been in Indonesia from generation to generation.

\subsubsection{Being Rich}

The common perception of Chinese Indonesians is that they are rich people. In Ngenest, the school bandits who are non-Chinese Indonesians choose Chinese Indonesians as the target of extortion, because Chinese Indonesians are seen as rich people. It is shown when Ernest is on the bus by himself, and suddenly students from STM (Vocational Technical School) who are not Chinese Indonesians come to him to extort him. They know that the moment they see Chinese Indonesians is the perfect day they can get benefits from them. From this scene, Chinese Indonesians become the target of non-Chinese Indonesians even though they are under the same nationality. Non-Chinese Indonesians think that being a target shows that there is a boundary between the non-Chinese Indonesians and the Chinese Indonesians, which shows that they are seen as "the other". The boundaries between the Chinese Indonesian and non-Chinese 
Indonesians in this scene shows the perception that Chinese Indonesians are rich people and non-Chinese Indonesians choose to target them because they are very "rewarding".

\subsection{The Reasons Why Chinese Indonesians Are Constructed as Such}

In Ngenest, Chinese Indonesians are constructed as foreign others because of the stereotype that non-Chinese Indonesians have toward the Chinese Indonesians. The stereotype produces prejudice, that is, a negative attitude towards an individual who belongs to a certain social group (Mcleod, 2008). According to Bolaffi, Bracalenti, Braham, \& Gindro, prejudice is characterized by narrow-mindedness, which is not justified by facts $(2002$, p.227). Prejudice is the result of stereotype, that is how people perceive others usually pejoratively (Dovidio, Hewstone, Glick, $\&$ Esses, 2010, p. 8). In the case of Chinese Indonesians, they are labeled as rich because of exploiting other groups of people and having loyalty to Chinese culture which means they have no loyalty to Indonesia. Thus, they are considered as "the other". Their rich label has a negative connotation (Chua, 2014). However, the view that Chinese Indonesians are rich because of exploiting others is not based on facts. It is a prejudice that the non-Chinese Indonesians cast upon the Chinese Indonesians. In this part, I will show the prejudice that occurs in Ngenest is the result of stereotype of Chinese Indonesians that lingers in the society. In Ngenest, Chinese Indonesians are constructed as foreign others because of the stereotype that nonChinese Indonesians have toward the Chinese Indonesians. The stereotype produces prejudice, that is, a negative attitude towards an individual who belongs to a certain social group (Mcleod, 2008). According to Bolaffi, Bracalenti, Braham, \& Gindro, prejudice is characterized by narrow-mindedness, which is not justified by facts (2002, p.227). Prejudice is the result of stereotype, that is how people perceive others usually pejoratively (Dovidio, Hewstone, Glick, $\&$ Esses, 2010, p. 8). In the case of Chinese Indonesians, they are labelled as rich because of exploiting other groups of people and having loyalty to Chinese culture which means they have no loyalty to Indonesia. Thus, they are considered as "the other". Their rich label has a negative connotation (Chua, 2014). However, the view that Chinese Indonesians are rich because of exploiting others is not based on facts. It is a prejudice that the non-Chinese Indonesians cast upon the Chinese Indonesians. In this part, I will show the prejudice that occurs in Ngenestis the result of stereotype of Chinese Indonesians that lingers in the society.

When Meira is having an argument with her father, Meira's father sees Ernest as Chinese Indonesians whom he dislikes. In his perception, he believes that Chinese Indonesians are stereotyped as Bad People as seen in picture 3.

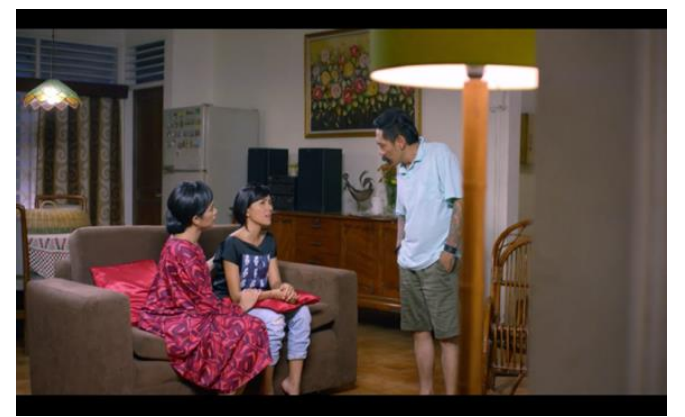

Picture 3: Meira's father asks Meira to stop her relationship with Ernest (Ngenest; 2015, 00:36:28 )

MEIRA'S FATHER Listen to me. It's enough that I was disappointed by them. You don't need to be.

MEIRA Dad, don't be like that. You shouldn't generalize. You went bankrupt because you were scammed by a Chinese Indonesian, 
but that doesn't mean that all Chinese Indonesians commit fraud.

MEIRA'S FATHER What do you know?

MEIRA Also, I've just met Ernest. I've only been out with him twice.

MEIRA'S FATHER Listen to me. A small flame is easier to put out compared to a fire that has grown larger over time.

Meira's father stereotypes Ernest as a Chinese Indonesian who is bad like the rest of the Chinese Indonesians. His stereotypical image of Ernest as a bad person comes from his experience with the Chinese Indonesians as what he has mentioned. However, his experience is personal and not applicable to all Chinese Indonesians. Meira's father opinion can be explained through Lippman's idea of Stereotype. According to Lippman, people do not first see, and then they can define, but people define first and then see the reality (Lippman, 1927). Meira's father does not see first and then define, but he has taken a definition that generalizes Chinese Indonesians as bad people and results in prejudice. Meira's father rejects Ernest directly because Ernest is a Chinese Indonesian. He has a definition that is strengthened by his experience that Chinese Indonesians need to be avoided. Since he believes that Chinese Indonesians are bad people, the way he acts toward Ernest becomes different.

\section{CONCLUSION}

In conclusion, Chinese Indonesians are constructed as perpetual foreigners because of their phenotypical features, being outsiders, and also being loyal to Chinese traditions, which makes them different from the rest of the Indonesian society, and as Chinese Indonesians are rich because of exploiting non-Chinese Indonesians. They are constructed that way as the result of a stereotype that lingers in the society. The stereotype that is pervasive in the society results in prejudice. Because of this prejudice, they are socially unaccepted. They are rejected in their own society because of prejudice, and stereotype has a role in making a prejudice. The stereotype that happens in the mind of people results in making non-Chinese Indonesians show bad attitudes toward Chinese Indonesians. Since Chinese Indonesians are not accepted in their own society because of the prejudice that is made by the society, Ernest tries to fight the oppression of society. In the story, Ernest tries to be low-profile by being succumbed to society's oppression. He tries to get along with non-Chinese Indonesians and even marries a Chinese Indonesian.

\section{REFERENCES}

Afrisia, R.S. (2017, November 12). Daftar Lengkap Pemenang Piala Citra FFI 2017. Retrieved from https://www.cnnindonesia.com/hiburan/20171111235005-220-255046/daftarlengkap-pemenang-piala-citra-ffi-2017

Bolaffi, G., Bracalenti, R., Braham, P., \& Gindro, S. (2002). Dictionary of Race, Ethnicity and Culture. London, United Kingdom: SAGE Publications.

Chua, C. (2004). Defining Indonesian Chineseness under the New Order. Journal of Contemporary Asia,34(4), 465-479.

Comedy. (n.d.). In Oxford Learner's Dictionaries online. Retrieved from https://www.oxfordlearnersdictionaries.com

Diananto, W. (2017, February 06). Film "Cek Toko Sebelah" 2,5 Juta Penonton, Ernest Prakasa: Ini Barang Bagus. Retrieved from https://www.tabloidbintang.com/film-tvmusik/kabar/read/59711/film-cek-toko-sebelah-25-juta-penonton-ernest-prakasa-inibarang-bagus

Diananto, W. (2018, December 23). Film Indonesia Paling Berkilau 2018: Susah Sinyal (2,17 juta penonton). Retrieved from https://www.tabloidbintang.com/film-tv- 
musik/kabar/read/119247/film-indonesia-paling-berkilau-2018-susah-sinyal-2-17-jutapenonton

Diffen. (n.d.). Ethnicity vs. Race. Retrieved from https://www.diffen.com/difference/Ethnicity_vs_Race

Djaya, A. B. (2016, March 11). Ngenest dan Single unggulan terbanyak di Indonesian Box Office Movie Awards. Retrieved from https://beritagar.id/artikel/seni-hiburan/Ngenestdan-single-unggulan-terbanyak-di-indonesian-box-office-movie-awards

Dovidio, J. F., Hewstone, M., Glick, P., \& Esses, V. M. (n.d.). Prejudice, Stereotyping and Discrimination: Theoretical and Empirical

Feliciano, C. (2015). Shades of Race. American Behavioral Scientist, 60(4), 390-419.

Hawari (2017, December 17). Ini Daftar Lengkap Pemenang Piala Maya 2017. Retrieved from https://hot.detik.com/movie/3773127/ini-daftar-lengkap-pemenang-piala-maya-2017

Katadata (2016, September 24). Film Bergenre Aksi Paling Banyak Tayang di Bioskop Indonesia. Retrieved from https://databoks.katadata.co.id/datapublish/2016/09/24/filmbergenre-aksi-paling-banyak-tayang-di-bioskop-indonesia

Kuntjara, E., Suprajitno, S., \& Djundjung, J. M. (2018). Surviving Chineseness in Chinese Indonesian Wedding Celebration. Journal of Chinese Literature and Culture,6(2), 1-18.

Lippman. (1922). Public Opinion. New York, NY: Harcourt, Brace and Company.

Mcleod, S. (2008). Prejudice and Discrimination. Retrieved from https://www.simplypsychology.org/prejudice.html

Nagel, J. (1994, February) Constructing Ethnicity: Creating and Recreating Ethnic Identity and Culture. Social Problems, 41(1), 152-176.

Nagel, J. (2000) Ethnicity and Sexuality. Annual Review of Sociology, 26, 107-133.

Perdana, G. (2016, December 19). Daftar Lengkap Pemenang Piala Maya 2016. Retrieved from https://www.liputan6.com/showbiz/read/2681981/daftar-lengkap-pemenang-pialamaya-2016

Pramantie, C. (2017, March 30). Menengok 10 Film Indonesia Terlaris Dalam 10 Tahun Terakhir. Retrieved from https://kumparan.com/@kumparanhits/menengok-10-filmindonesia-terlaris-dalam-10-tahun-terakhir

Theresia, H. (2018, March 29). Film Indonesia : Sejarah Yang Terabaikan [Videofile]. Retrieved from https://www.youtube.com/watch?v=IvfKo5vGr7w

Wahyudi, T. (2018, December 17) 10 Film Indonesia Terlaris di Tahun 2018. Retrieved from https://id.bookmyshow.com/blog-hiburan/10-film-indonesia-terlaris-di-tahun-2018/ 